\title{
Classroom Management and Student Achievement: A Study on Five Elementary
}

\author{
Classrooms $^{12}$ \\ Nevin GÜNER YILDIZ \\ Eskisehir Osmangazi University, Turkey \\ antreh@gmail.com
}

\begin{abstract}
This study intended to investigate primary school teachers' classroom management and student achievement in their classrooms. For this purpose, a total of 150 class-hours were spent on observing one first grade and four second grades in a primary school in Eskisehir city center between October 2013 and December 2013. Research participation criteria for teachers included volunteering for the study and having at least one special needs student in their classrooms for observation so that teacher behaviors towards the special needs students could be observed Researcher-developed observation form was used in the study for data collection purposes to record teachers' classroom management practices during observations. The form included several dimensions related to classroom management behaviors such as the exact moment of the lesson in which the teacher starts teaching, the locations of special needs students during the class period, use of rewards-punishment for special needs students and other students, use of individualized care for special needs students and the degree of effective use of classroom period. Data related to student achievement were obtained from the results of a general achievement test given to all students at the school based on their grade levels. Research data were analyzed via descriptive statistics and one way analysis of variance (ANOVA) to determine the difference between groups. The findings showed that teachers tended to place special needs students at the back rows of the classroom and that they did not provide individualized teaching opportunities in line with the needs of special needs students. It was also found that number of correct answered in the general achievement test significantly changed according to students' teachers.
\end{abstract}

Keywor ds: Classroom management, Student achievement, Students with special need

\footnotetext{
${ }^{1}$ Research paper, Received: 13.06.2016 Accepted: 16.01.2017

${ }^{2}$ A preliminary report of this study was presented at the 24st National Special Education Congress, held in 2014 in Edirne.
} 


\section{Introduction}

Teacher qualifications and behaviors affect student achievement and behaviors. Student achievement can be regarded as the most important output of education. Expectations and pursuit of different groups such as students, families and educators in terms of achievement have resulted in various studies by researchers focusing on the factors that explain student achievement. Several studies that focus on student achievement address topics such as the effects of teacher or familial expectations on student achievement (Phillipson and Phillipson, 2012; Segedin, 2012), relationship between achievement and the period allocated to learning (Özer and Anil, 2011; Savaş and Gürel, 2014) and effects of feelings such as belonging to school and being accepted at school on achievement (Lemberger and Clemens, 2012; Kosir and Tement, 2013). However, when it comes to student achievement, the emphasis is on teachers since teacher qualification is a more important factor compared to other school factors in increasing student achievement (Akiba, Le Tendre and Scribner, 2007) and since the proof has been presented about the strong relationship between teacher generated classroom climate and teaching methods, which may be classified as classroom methods, and student achievement by various researchers (Wang, Haertel and Walberg, 1994; Wright, Horn and Sanders, 1997). The fact that teachers are prominent factors in ensuring student achievement has led many researchers to study the relationship between teachers and student achievement. Studies in the field emphasize issues such as increased achievement in disciplined classrooms (Akyüz, 2006), importance of teachers in ensuring academic focus by decreasing undesired behaviors and increasing desired behaviors (Kunter, Baumert and Köller, 2007), existence of the relationship between achievement and teacher qualifications (Akiba, Le Tendre and Scribner, 2007; Darling-Hammond, 1999; Gallagher, 2002; Tomlinson and Jarvis, 2014) and the need for teachers to adapt and regulate the environmental variables 
in order to increase student achievement (Baker, Clark, Maier and Viger, 2008). The common aspect of all these studies is the investigation of teacher qualifications and behaviors as the most important factor on student achievement.

Teacher behaviors affect student interest towards the lessons and their study habits and therefore their achievement. Student interest and participation can be increased through the use of effective classroom management techniques. It is emphasized by different researchers that the students of teachers who effectively manage their classrooms participate in classes more, student achievement increases via more participation in classes and problem behaviors decrease (Emmer and Stough, 2001; Evertson, 1989; Marzano, Marzano and Pickering, 2003). Various behaviors of teachers who manage their classrooms well are listed in the literate. Teachers, who effectively use classroom management such as teach effectively, reward appropriate behaviors, impose sanctions on inappropriate student behaviors, adapt lessons based on student characteristics and effectively use the lesson period can increase student achievement and desired behaviors (Emmer and Stough, 2001; Gettinger and Kohler, 2006). A study that examined evidence-based practices in classroom management (Simonsen, Fairbanks, Briesch, Myers and Sugai, 2008) emphasized that teachers can increase students' on task study behaviors by using strategies such as identifying and teaching classroom rules, monitoring student behaviors, rewarding appropriate student behaviors, displaying consistent responses to inappropriate student behaviors and ensuring student participation via different teaching methods. Teachers who use classroom management techniques that have been proven to be effective manage their classroom better and positively affect student achievement and behaviors.

Teachers should be aware of student characteristics and needs for a good classroom management (Marzano, Marzano and Pickering, 2003) which increases student participation and achievement (Emmer and Stough, 2001). Since students' individual characteristics and 
needs are different from one another, teachers should be flexible to adapt their teaching based on student abilities, previous information levels and learning paces. Although teachers sometimes undertake educational adaptations to meet the different needs of typically developing students in their classrooms, they may tend to behave differently when it comes to students diagnosed as special needs students. It is known that teachers may tend to regard the differences of special needs students as a source of problems rather than as a dimension in regulating teaching or as the basis for adaptation (Cook, Cameron and Tankersley, 2007). However, it is emphasized in literature that teacher attitudes and behaviors are the most important factors for student achievement in inclusion classrooms just like in the other classrooms (Soodak and McCarthy, 2006).

Inclusion practices that ensure teaching special needs students in the same classrooms with typically developing students have become common with the acceptance of PL 94-142 principles in the whole world after PL 94-142 went into effect in USA in 1975. Although it has been 40 years since the acceptance of these principles, problems regarding practices in the field of inclusive education still continue. The fact that teachers and teacher candidates do not have sufficient information related to inclusive education, that they do not feel ready for inclusive education, that they feel special needs students should be educated in separate schools show that teachers have a common and negative outlook to inclusive education both in the world (Cook, 2002; Cullen, Gregory and Noto, 2010; Hemmings and Woodcock, 2011; Thaver and Lim, 2014) and in Turkey (Gökdere, 2012; Korkmaz, 2011; Sadioğlu, Bilgin, Batu and Oksal, 2013; Sucuoğlu, Bakkaloğlu, İşcen-Karasu, Demir and Akalın, 2014; Varher and Vuran, 2006). Although legal arrangements related to special education in Turkey are based on teaching special needs students with their peers in the same environment assisted by support services (Statutory Decree no. 573, 1997: Articles 4, 12 and Special Education Services Regulations, 2006: Article 6), inclusive education practice is limited to placing 
special needs students in general education classrooms (Sakı and Woods, 2015). Inclusive education which needs to be unrestricted since it is a legislative right (Hansen, 2012) can only be undertaken in a limited manner in Turkey due to problems such as crowded classrooms, deficiencies in assessment processes and incompetence of general education teachers as well as due to problems in comprehending the philosophy that underlines the practice (Sakiz and Woods, 2015). Teachers have common beliefs regarding inclusive education especially in two points: First, teachers believe that special needs students take too much of teachers' time; second they believe that teaching special needs students require special abilities that general education teachers do not possess (Broomhead, 2013; Cullen, Gregory and Noto, 2010).

Several factors can be considered as effective in forming teachers' consensus in terms of special needs students and inclusive education. For instance, the fact that special needs students are described with negative characteristics and deficits as individuals with learning problems who are impulsive, aggressive, self-destructive and uncontrolled in university textbooks can result in establishing an over generalized perspective towards these individuals (Güner-Yıldı, Sazak-Pmar and Melekoğlu, 2014; Morrison and Rude, 2002). As a result of this point of view, teachers may regard "special needs" as a cause for problem behaviors (Smith, 2000) and tend to refuse to take with special needs students or pay sufficient attention to them even if these students are registered in their classrooms (Cook, Cameron and Tankersley, 2007). Secondly, generally negative social perspective towards the disabled people (Güner-Ylddz, 2015a) may be considered as a factor that affects teacher views and behaviors as well. Views of the dominant groups in the society that regard the disabled as a burden and that reject their existence and their preferences are paving the way for excluding the individuals without typical developmental patterns from general education classrooms (Ballard, 2013). Although it is understandable that teachers adopt a generally accepted social outlook as members of society, it cannot be accepted. Since successful and equalitarian 
inclusive education requires competent, willing and responsive teachers (Killoran, Woronko and Zaretsky, 2013), it is imperative to investigate and develop teacher qualifications and behaviors. Examining teacher characteristics and behaviors in classrooms where inclusive education is practiced is crucial to obtain data that will form the foundation for effective teaching practices in these classrooms.

Several studies undertaken in the classrooms where inclusion practices were implemented can be found in the literature. Some of these studies focused on teacher views, skills and behaviors related to classroom management. Topics such as effects of working with a resource teacher on teachers' inclusive education provision skills (Thomson, 2013), views of general education teachers on necessary arrangements regarding the special needs students in their classrooms (Kargin, Güldenoğlu and Şahin, 2010), effects of focusing on students on student participation in class (Logan, Bakeman and Keefe, 1997), relationship between the quality of Individualized Education Program (IEP) and student participation in class (Ruble and McGrew, 2013), effects of field experience on special and general educators' knowledge and skills (Hanline, 2010), characteristics of teacher and student behaviors in inclusive education classrooms and their relationships (Güner-Y1ldı, 2015b; Güner-Yıldız and SazakPmar, 2012; Sazak-Pmar and Güner-Y1ldz, 2013) can be cited as the research topics investigated by researchers both abroad and in Turkey. However, studies on student achievement in inclusive general education classrooms are limited. One of these limited studies investigated the quality of IEP in America as an important factor for increasing special needs students' achievement (La Salle, Roach and McGrath, 2013). The study that was based on the premise that quality of IEP and students' test achievement were related found that goals in the investigated IEPs were of varying quality and that sufficient ties were not formed between goals and student performances. A second study in the field undertaken in our country examined how teachers assessed inclusive education students' achievements via 
teacher views by investigating 25 teacher views (Güven and Gürsel, 2014). These studies did not focus on the achievement of students in general education classrooms but investigated IEP quality and teacher views in connection with special needs students' achievement. It is evident in literature that studies on teacher behaviors and student achievement in general education classrooms where special needs students are enrolled are limited. It is possible to examine student achievement in general education classrooms from different dimensions such as achievement of special needs students, achievement of students with typical developmental patterns and the effects of teacher behaviors on students.

By focusing on a relatively less studied topic in literature, this study intended to investigate teacher behaviors and student achievement in general education classrooms that include special needs students in two dimensions: The first dimension aimed to describe classroom management behaviors of general education classroom teachers and their behaviors towards students with special needs and the second dimension investigated whether teachers' behaviors were related to the classroom's average exam success.

This study, which is expected to fill a gap in the literature by focusing on teachers' classroom management behaviors in general education classrooms, their behaviors towards special needs students and examining these variables by associating them with classroom achievement, sought to answer the questions below:

1.What classroom management behaviors do the teachers assigned to general education classrooms display and how do they behave towards the students that they think to be special needs students?

2.Do students' exam achievement in general education classrooms significantly change according to teachers' classroom management behaviors? 


\section{Methodology}

\section{Research Model}

This study was designed as a descriptive and relational study. Educational researchers undertake relational studies to present the relationships between variables related to situations/cases or events that go beyond simply describing them (Büyüköztürk, Kıllı̧Çakmak, Erkan-Akgün, Karadeniz and Demirel, 2014). This study aimed to describe the behaviors of classroom teachers assigned to general education classrooms and identify the relationship between these behaviors and student achievement.

\section{Study Group}

Data were collected in a total of five classrooms (one first grade and four second grades) in a primary school situated in Eskisehir city centre. Criteria for selecting the classrooms for the study included volunteer participation by teachers and having at least one student in the classroom who is thought to be a special needs student by the participating teacher. Special needs students in the study seem to have been identified as special needs students by the teachers themselves and in actuality these students do not have diagnoses because although teachers had actually wanted to send these students to Research and Guidance Center for examination, their parents did not want their children to be diagnosed and therefore the students were not examined in that regard.

While the primary school in which the study was carried out have more than 20 first and second grades, teachers with no students that are relatively different from the norm and no special needs students were not taken in the framework of the study and therefore the study was limited to five classrooms that met the criteria. The number of students in these classrooms changed between 29 and 30. Four of the students qualified as special needs by the 
teachers were males and one was female. Three of the classroom teachers participating in the study were males and two were females between the ages of 38 and 50 .

\section{Data Collection Tools}

As data collection tools, class observations were used to identify teacher behaviors and a school wide achievement test was utilized to determine student achievement. An observation form was developed by the researcher to be used in class observations to identify teacher behaviors. The observation form in which teachers' classroom management practices were recorded includes the teacher behaviors listed in Table 1 . Teacher behaviors listed in Table 1 were recorded via observations undertaken a total of 150 class hours in 5 separate classrooms and the results provide 150 separate pieces of data related to each behavior.

Table 1

Behaviors listed in teacher observation form

1 During the class period, at which minute does the teacher starts and completes the lesson?

2 During the class period, what is the frequency of non-academic teacher behaviors such as answering the phone, talking with a classroom visitor, talking about a topic unrelated to the class or talking with a student who is asking for permis sion to leave the classroom?

3 What is the level of interaction between the teacher and the special needs student during the lesson? (Teachers' academic interaction with the special need students such as asking questions, helping, drawing attention, telling what to do was recorded separately as 1).

4 Does the teacher provide adaptations for the special needs student? (If the student is working on a task which is appropriate for his/her individual needs and that is different from the rest of the classroom the response was recorded as "yes" and if the student is working on the same tasks as the classroom the response was recorded as "no".

5 What is the number of rewards-punishments given to students with special needs, and typical developmental patterns? (Each reward and punishment/warning/behavior of disapproval used by the teacher for students with special needs, and typical developmental patterns was recorded as 1 .

6 Where does the special needs student sit in the clas sroom?

In addition, observers assessed the teachers' classroom management for each lesson for 10 characteristics with the help of a section added at the end of the observation form and gave each teacher a classroom management score. The behaviors cited in the list which included effective classroom management strategies used by teachers who manage their classrooms very well (Gettinger and Kohler, 2006; Jones and Jones, 2001) define teacher behaviors that 
aim to enhance student achievement by increasing their in-class participation, facilitate comprehension and teaching effectively. This assessment list which reflects subjective perspectives of the observers and which allows teacher assessment on a 1-10 scale by assigning a point to each behavior includes the behaviors listed in Table 2. Since each of the five teachers were observed 30-class hours, their classroom management assessment scores was formed by taking the average of the scores given for 30 separate lessons.

\section{Table 2}

\section{Classroom management behaviors scored by the observers}

1 Does the teacher link the topic to previous topics or to daily life?

2 Does the teacher teach the topic in a consistent order from easy to more difficult and without jumping from topic to topic?

3 Does the teacher draw student attention to the topic by avoiding unrelated topics and concepts?

4 Does the teacher provide sufficient number of examples to objectify the topic?

5 Does the teacher provide more than one activities during class by using different teaching methods and materials?

6 Does the teacher use simple and intelligible language?

7 Does the teacher ensure the maintenance of student interest by asking questions related to the lesson?

8 Does the teacher ensure that all students listen to both presentation of the lesson and the questions that are asked?

9 Does the teacher allow for sufficient time for the student to provide an answer?

10 Does the teacher check for comprehension and re-teach the topic if it is not understood?

Data regarding student achievement were obtained from the results of a school-wide general achievement test jointly given to students in the same class levels. The exam prepared by an educational company to review the topics studied by students so far was composed of a total of 42 questions (15 Turkish, 15 Mathematics and 12 Social Sciences). Assessment of the test which was given in the same date in different provinces under similar conditions and calculation of students' achievement scores were undertaken by the company which organized the test as well. Exam results which made it possible to compare students on the basis of provinces, districts and schools were given to schools in the form of lists by the educational company which prepared the test so that teachers were able to establish the placement level of their students in comparison to a wide sample. All classrooms in the study except the first 
grade classroom participated in this exam and the exam results were obtained by the researcher from the list given to the teachers. Exam result lists provided detailed data such as student scores, number of correct answers and placement on the basis of their school and in the district and in the province as well as among provinces. Since the exam result lists included different variables such as previous achievement scores and weighted lesson scores used by the company in calculating achievement scores, this study used the number of correct answers in analysis.

\section{Process}

Training of Observers: Five undergraduate students attending Eskisehir Osmangazi University Special Education Department were trained to provide classroom observations. Training started with a meeting in which the candidates for observation were explained by the researcher about general topics about scientific studies such as scientific research methods, rules to follow during scientific studies, qualities that studies should include and research ethics. Later, information was provided about the topic of the current study, method and data collection tools. Following the information about the general topics, candidates were informed of the characteristics of classroom observations planned for the candidates in the framework of the study. The candidates were informed of the purpose of classroom observations, the content of the data collection tool that would be used in the observations, rules to follow during observations and how the data collection tool would be marked and later they were provided with opportunities for trial. Trial observations included watching lesson videos recorded in primary classrooms. Observer training continued by having candidate observers and the researcher watch three separate classes of a teacher and fill observation forms. Comparison of the consistencies in the observation forms for three classes showed 57\% lowest and $86 \%$ highest consistency between the researcher and the candidate observers. Later the reasons for inconsistent assessment were discussed with the candidate observers and the 
points that needed to be taken into consideration were reviewed again. As the last step, two sample lesson videos were watched by the researcher and the candidate observers and observation forms were filled. The comparison of the observation forms pointed to $86 \%$ lowest and $100 \%$ highest consistency between the researcher and the candidate observers and the training completed at this point.

Data Collection Period: A total of 150 class hours (30 separate class hours in each classroom) were observed between October and December 2013. The observations took place in different lessons and periods for the full class period. During observations, it was ensured that teachers made presentations, had practices with the students and undertook other academic activities related to class. When teachers were busy with giving exams, had other activities other than the class topic or left the classroom in the care of another teacher, observations were not done and the same classrooms were visited again at another date for observation. Observers went to the classrooms five minutes before lessons started and took their place at the back of the classrooms; observation started when the teacher came to the classroom and continued until the minute the lesson was completed by the teacher.

To ensure reliability in observations, the researcher and observers observed the lessons in parallel to each other in 30 lesson hours out of 150 and inter-rater reliability was calculated. Inter-rater reliability is the comparison of two independent observers who use independent but concurrent assessments as to whether a target behavior exists (Alberto and Troutman, 2006) and the following formula was used to calculate inter-rater reliability. Inter-rater reliability= [(agreements / agreements + disagreements $)]$ x 100.

The level of consistency in parallel observations provided by the researcher and the observers was as follows: $78 \%$ consistency in two observations, $85 \%$ in five observations, $92 \%$ in 
fifteen observations and $100 \%$ in eight observations and it was determined that consistency average in parallel observations was $92 \%$.

Data Analysis: Research data were analyzed using descriptive statistics and one way variance of analysis (ANOVA) test to determine the difference between groups.

\section{Findings}

Average teacher behaviors displayed in a class hour were calculated based on the observations undertaken for 30-hour each in five classroom teachers' classrooms. Table 3 presents the following information respectively: the minute in which the teacher starts the lesson after the lesson period starts (starting the lesson), the time period in which the teacher finishes the lesson before the lesson period ends (finishing the lesson), sum of lost time during starting and finishing the lesson (total time loss), the number of interruptions due to non-academic reasons (interrupting the lesson), frequent of academic teacher interactions with special needs students (academic with SEN), whether the teacher provides adaptations in instruction for special needs students (adaptation), the placement of special needs students in the classroomin which row (SEN placement), number of rewards and punishments/warnings/disapproval behaviors used by teaches for special needs students (SEN reward/SEN punishment), number of rewards and punishments/warnings/disapproval behaviors used by teaches for students with typical developmental patterns (Other students reward/ Other students punishment), score given to teachers by the observers (teacher average score) and the number of correct answers in student's achievement test (exam average correct answer). 
Table 3

Teachers' classroom management behaviors and average correct numbers in student achievement tests

\begin{tabular}{|c|c|c|c|c|c|c|c|c|c|c|c|c|c|}
\hline Class & 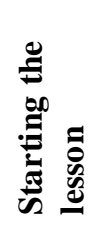 & 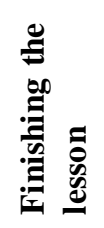 & 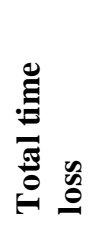 & 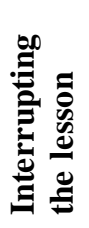 & 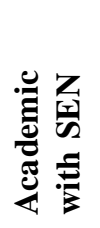 & 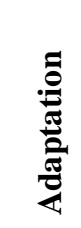 & 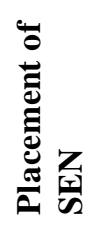 & 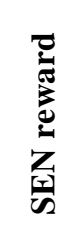 & Z & 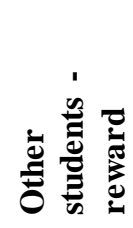 & 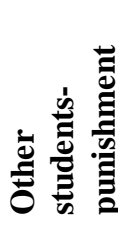 & 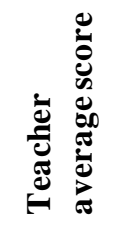 & 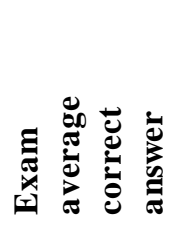 \\
\hline 1-D & 2,3 & 2,4 & 4,7 & 3,5 & 2,5 & 0 & 4,9 & 0,2 & 2,0 & 7,0 & 18,2 & 5,83 & \\
\hline 2-C & 10,3 & 1,6 & 11,9 & 2,5 & 0,2 & 0 & 5,8 & 0 & 0,7 & 2,6 & 20,0 & 6,37 & 27,1 \\
\hline 2-D & 6,5 & 0,7 & 7,2 & 1,1 & 1,6 & 0 & 4,4 & o & 0,9 & 4,0 & 21,3 & 6,43 & 27,3 \\
\hline 2-F & 4,3 & 0,2 & 4,5 & 1,6 & 1,4 & 0,1 & 4,0 & 1 & 0,5 & 29,3 & 23,5 & 8,97 & 34,8 \\
\hline 2-J & 11,1 & 0,4 & 11,5 & 2,8 & 1,6 & 0 & 3,7 & 0,2 & 0,2 & 3 & 17,5 & 6,37 & 29,7 \\
\hline $\mathbf{X}$ & 6,9 & 1,06 & 8 & 2,3 & 1,5 & 0,02 & 4,6 & 0,3 & 0,9 & 9,2 & 20,1 & 6,8 & 29,7 \\
\hline
\end{tabular}

Table 3 shows that total time loss, calculated on the basis of the minutes in which teachers start and finish the lessons, was rather high (an average of 8 minutes in a 40-minute lesson period) and it was found that the lesson was interrupted 2 or 3 times for non-academic tasks. The Table also points to the facts that teacher interactions with special needs students in a class hour was very little (an average of 1,5 times), that none of the teachers, other than $2 \mathrm{~F}$ classroom teacher, made adaptations for special needs students and that special needs students were placed at the back rows (fourth row or farther back). In terms of use of rewards and punishments, teachers were observed to use rewards very little (an average of 0,3 times in a class hour) for special needs students, the use of punishments/warnings/disproval behaviors were three times higher than those of rewards (an average of 0,9 times in a class hour) and teachers tended to use punishments/warnings/disproval behaviors for all students (special needs students and other students) more than the use of rewards. Based on the observers' scores, the highest score was obtained by $2 \mathrm{~F}$ classroom teacher $(8,97$ out of 10$)$ and it was found that students in this teacher's classroom answered more correct questions (an average of 34,8 correct answers) compared to students in the other classrooms. 
Table 4

Results of One-Way ANOVA undertaken to determine whether time loss differed according to teachers

\begin{tabular}{lllllll}
\hline $\begin{array}{l}\text { Source of } \\
\text { Variation }\end{array}$ & $\begin{array}{l}\text { Sum of } \\
\text { Squares }\end{array}$ & sd & $\begin{array}{l}\text { Mean } \\
\text { Squares }\end{array}$ & F & P & $\begin{array}{l}\text { Significant } \\
\text { Difference }\end{array}$ \\
$\begin{array}{l}\text { Between } \\
\text { groups }\end{array}$ & 1132,358 & 3 & 377,453 & 19,049 &, 000 & $1-2,1-3$, \\
$\begin{array}{l}\text { Within } \\
\text { Groups }\end{array}$ & 2298,567 & 116 & 19,815 & & & \\
Total & 3430,925 & 119 & & & & \\
\hline
\end{tabular}

As can be seen in Table 4, results of analysis pointed to significant differences between teachers in terms of time loss $[\mathrm{F}(3-116)=19.05, \mathrm{p}<.01]$. Results of Scheffe test, undertaken to determine the source of difference showed that time loss for $2 \mathrm{~F}$ classroom teacher $(X=4.53)$ and for $2 \mathrm{D}$ classroom teacher $(X=7.17)$ were significantly less than those of $2 \mathrm{C}$ and $2 \mathrm{~J}$ classroom teachers $(X=11.9$ and $X=11.5)$. The calculated effect size was found to be at medium level $(\eta 2=.33)$.

Table 5

Results of One way ANOVA undertaken to determine whether students' correct answers in the achievement test differed according to teachers

\begin{tabular}{lllllll}
\hline $\begin{array}{l}\text { Source of } \\
\text { Variation }\end{array}$ & $\begin{array}{l}\text { Sum of } \\
\text { Squares }\end{array}$ & sd & $\begin{array}{l}\text { Mean } \\
\text { Squares }\end{array}$ & F & P & $\begin{array}{l}\text { Significant } \\
\text { Difference }\end{array}$ \\
$\begin{array}{l}\text { Between } \\
\text { groups }\end{array}$ & 1135,625 & 3 & 378,542 & 10,769 &, 000 & $3-1 / 2 / 4$ \\
Within Groups & 4077,367 & 116 & 35,150 & & & \\
Total & 5212,992 & 119 & & & & \\
\hline
\end{tabular}

Table 5 shows significant differences between correct student answers in the achievement test based on their teachers $[\mathrm{F}(3-116)=10.77, \mathrm{p}<.01]$. Results of Scheffe test, undertaken to determine the source of difference between teachers showed that students in $2 \mathrm{~F}$ classroom had significantly more correct answers $(\mathrm{X}=34.8)$ compared to the students in the other three 
classrooms $(2 \mathrm{C}, 2 \mathrm{D}, 2 \mathrm{~J})(\mathrm{X}=27.1, \mathrm{X}=27.3, \mathrm{X}=29.7)$ The calculated effect size was found to be at a low level $(\eta 2=.22)$.

Table 6

Results of One way ANOVA undertaken to determine whether students' correct answers in the achievement test differed according to teachers' classroom management scores provided by the observers

\begin{tabular}{lllllll}
\hline $\begin{array}{l}\text { Source of } \\
\text { Variation }\end{array}$ & $\begin{array}{l}\text { Sum of } \\
\text { Squares }\end{array}$ & sd & $\begin{array}{l}\text { Mean } \\
\text { Squares }\end{array}$ & F & P & $\begin{array}{l}\text { Significant } \\
\text { Difference }\end{array}$ \\
$\begin{array}{l}\text { Between } \\
\text { groups }\end{array}$ & 1034,225 & 2 & 517,112 & 14,478 &, 000 & $6,37-8,97$ \\
Within Groups & 4178,767 & 117 & 35,716 & & & $6,43-8,97$ \\
Total & 5212,992 & 119 & & & & \\
\hline
\end{tabular}

Table 6 shows that the number of correct answers provided by the students in the achievement test significantly differed according to the scores given to teachers by the observers $[\mathrm{F}(2-$ $117)=14,48, \mathrm{p}<.01]$. Results of Scheffe test, undertaken to determine the source of difference between student averages showed that the average correct number of $2 \mathrm{~F}$ students in the test $(X=34.8)$ were significantly higher than those of students in the other three classrooms $(2 \mathrm{C}$, 2D, 2J) $(X=27.1, X=27.3, X=29.7)$. The calculated effect size was found to be at a low level $(\eta 2=.20)$

\section{Discussion}

This study intended to describe classroom management behaviors of teachers teaching in general education classrooms that included special needs students along with students with typical developmental patterns and to determine whether classroom achievement score changed according to teachers' classroom management behaviors. According to the findings, teachers displayed insufficient classroom management behaviors. For instance, it was found that an average 8 minute loss was experienced in a 40-minute lesson period due to teachers' coming to classroom late or finishing the lesson earlier than the norm. In addition to this time 
loss, the fact that the lesson was interrupted 2 or 3 times due to non-academic tasks also added to the time loss and the lesson period which was meant for academic tasks decreased. However, it is emphasized in the literature that one of the factors that predict student achievement is the time allocated for learning (Özer and Anıl, 2011; Savaş and Gürel, 2014). In order to increase the time allocated for learning, teachers should use the lesson periods effectively and ensure that students spend their time on academic tasks by taking necessary precautions to increase student participation in class. Researchers highlight the facts that teachers' classroom management skills play important roles in maximizing academic interaction time between teachers and students (McGee, 2001) and that student participation in class can be ensured via effective teaching skills (Jordan, Schwartz and McGhieRichmond, 2009). Since high level of participation is related to achievement (Baker, Clark, Maier and Viger, 2008), it is emphasized in the literature that the best thing a teacher can do for student learning is to organize the classroom and the time in a manner that is free from interruptions (Evertson and Harris, 1992; Kunter, Baumert and Köller, 2007). Although it is crucial for achievement, time losses observed in the classrooms participating in the study point to the need for teacher training in effective use of classroom time.

When the findings related to the teacher behaviors towards students with special needs are examined, teachers were found not to display the behaviors that would facilitate special needs students' participation to the lessons. Studies emphasize the need for assigning level appropriate tasks for special needs students to ensure their engagement with academic tasks (Emmer and Stough, 2001). But the findings of this study revealed that only one of the five special needs students were able to receive level appropriate instructional adaptations from his/her teacher and only in some lessons. The identified level of teacher interaction frequency $(1,5)$ with special needs students is not sufficient to ensure academic participation of these students which is already too little (McIntosh, Vaughn, Schumm, Haager and Lee, 1993). The 
fact that special needs students were placed in the back rows in the classrooms can be regarded as a barrier for teachers to reach these students and often and easily display the required behaviors to keep them involved in the lesson. On the other hand, placement of special needs students at the back rows can be regarded as an indication for teachers' unwillingness to make special/extra efforts for their special needs. Although teachers who manage their classrooms well are teachers who not only know their content area very well but also know how to plan and teach the lessons by taking different needs into consideration as well (Berry, 2002), teachers are generally known to have negative attitudes when it comes to special needs students. For instance, in the interviews with classroom teachers, teachers stated that classroom teachers are incompetent in terms of special needs students and that special education is better for these students (Sadioğlu, Bilgin, Batu and Oksal, 2013). Similarly, in a study with pre-school teachers, teachers expressed that the felt inadequate to work with special needs students, had a hard time working with them and they felt uncomfortable having these students in their classrooms (Varler and Vuran, 2006). Studies abroad also provided similar results (Cook, 2002; Cook, Cameron and Tankersley, 2007; Hemmings and Woodcock, 2011). Findings of the current study support the previous findings that emphasize teachers' attitudes towards special needs students and the need to improve these practices. Existence of many special needs students -with or without diagnosis- in general education classrooms makes it imperative to train the teachers working in these classrooms in the area of special needs students. Literature reports that participation in various trainings or practices regarding inclusive practices in general education classrooms positively change teachers' attitudes (Gao and Mager, 2011; Killoran, Woronko and Zaretsky, 2013; Recchia and Puig, 2011; Van Laarhoven, Munk, Lynch, Wyland, Dorsch, Zurita, Basma and Rouse, 2006; Walton and Rusznyak, 2014). Trainings that will be provided for teachers working in inclusive classrooms should address special education, effective teaching and instructional 
adaptations and planning for trainings should include content that will make these teachers feel responsible for special needs students (Jordan, Schwartz and McGhie-Richmond, 2009).

When the frequency of behaviors related to use of rewards and punishments or warnings for special needs students and other students are examined, it was seen that punishments or warnings were more often used compared to rewards. While teachers made use of rewards an average of 0,3 times in a lesson for special needs students and used rewards 9,2 times for all other students in a class period, they used punishment of warning behaviors two times more for both groups. Three separate studies in inclusive classrooms (Güner-Yıldı, 2015b; GünerYıldız and Sazak-Pınar, 2014; Sazak-Pınar and Güner-Yıldız, 2013) identified that classroom teachers used punishing or warning behaviors defined as disproval more often compared to approval behaviors (rewards). In fact, the literature emphasizes that teachers should approve appropriate student behaviors -or in other words reward these behaviors- in order to increase desired behaviors and decrease problem behaviors and that teachers should use negative behavioral management techniques such as punishment as the last resort (Brophy, 2006; Landrum and Kauffman, 2006; Swinson and Harrop, 2001). It is identified that oral rewards are especially effective in decreasing students' problem behaviors (Ferguson and Houghton, 1992) and via rewarding students, teachers can ensure using the lesson time for academic tasks by decreasing the time spent with dealing with problem behaviors (Brophy, 1983; Chalk and Bizo, 2004). It is believed that researchers should study the reasons why teachers do not often use rewards despite its importance on managing student behaviors.

The study also examined whether student achievement differed according to classroom teachers. Based on the findings, achievements of $2 \mathrm{~F}$ students in the exam were significantly higher than those of other three classrooms. When classroom management behaviors of $2 \mathrm{~F}$ classroom teacher is examined, it was seen that, among the five teachers that participated in the study, this teacher had less time loss in classes and used rewards and punishments more. 
2F classroom teacher who used rewards an average of 29,3 times in a lesson used rewards four more times than the teacher who utilized the most number of rewards in the study and although he/she was the teacher who used the highest number of punishments/warnings, this finding was not significant since all other teachers used punishments/warnings behaviors to a high degree. It is known that teachers who effectively make use of class time increase student on-task behavior and are effective on student achievement (Baker, Clark, Maier and Viger, 2008; Kunter, Baumert and Köller, 2007). Use of rewards is defined as one of the effective elements in managing student behaviors (Landrum and Kauffman, 2006). The facts that $2 \mathrm{~F}$ classroom teacher used class periods effectively and gave 4 times more rewards compared to other classroom teachers in the study may have been effective in ensuring student achievement. 2F classroom teacher, the only teacher in the study who made adaptations for the special needs student in his/her class, albeit from time to time, seemed to ensure student achievement by letting the special needs student to succeed in the framework of his/her own abilities. Based on observer scores, this teacher who had the best classroom management skills among the five classroom teachers in the study was observed to display behaviors that would make students learn better. These behaviors which included linking the topic to previously learned topics, providing sufficient number of examples, using simple and intelligible language and checking comprehension to make sure the topic is understood are effective teaching behaviors. It is believed that using effective teaching methods, using more rewards, using the class period more effectively and adapting the instruction to the needs of the special need student differentiated $2 \mathrm{~F}$ classroom teacher and became instrumental in ensuring his/her students' achievement.

Teachers are important factors that can positively affect student achievement (DarlingHammond, 1999; Tomlinson and Jarvis, 2014). Findings of this study and many other studies emphasize the need for enhancing teacher skills in order to increase student achievement 
(Akiba, Le Tendre and Scribner, 2007; Gallagher, 2002). It is imperative to invest in teacher qualifications covering a wide range from undergraduate pre-service training to in-service trainings to ensure achievement both in inclusive education classrooms and for all other classrooms. And future studies should investigate the relationship between teacher behaviors and student achievement in special education settings.

*A preliminary report of this study was presented at the 24st National Special Education Congress, held in 2014 in Edirne. 


\section{References}

Alberto, P. A., \& Troutman, A. C. (2006). Applied behavior analysis for teachers (7th ed.). New Jersey: Pearson Merrill Prentice Hall.

Akiba, M., Le Tendre, K.L. \& Scribner, J.P. (2007). Teacher quality, opportunity gap, and national achievement in 46 countries. Educational Researcher, 36(7), 369-387.

Akyüz, G. (2006). Türkiye ve Avrupa Birliği ülkelerinde öğretmen ve sinıf niteliklerinin matematik başarısına etkisinin incelenmesi (Investigation of The Effect of Teacher and Class Characteristics on Mathematics Achievement in Turkey and European Union Countries). Illköğretim Online, 5(2), 61-74.

Ballard, K. (2013). Thinking in another way: ideas for sustainable inclusion. International Journal of Inclusive Education, 17(8), 762-775.

Baker, J. A., Clark, T. P., Maier, K. S., \& Viger, S. (2008). The differential influence of instructional context on the academic engagement of students with behavior problems. Teaching and Teacher Education, 24, 1876-1883.

Berry, B. (2002). What it means to be a "highly qualified teacher". Southeast Center for Teaching Quality, University of North Carolina (ERIC Document Reproduction Service No. ED 480580).

Broomhead, K.E. (2013). Preferential treatment or unwanted in mainstream schools? The perceptions of parents and teachers with regard to pupils with special educational needs. Support for Learning, 28(1), 4-10.

Brophy, J. (1983). Classroom organization and management. The Elementary School Journal, 83(4), 265-285.

Brophy, J. (2006). History of research on classroom management. In C. M. Evertson \& C. S. Weinstein (Eds.), Handbook of classroom management: Research, practice and 
contemporary issues (pp. 3-15). Mahwah, New Jersey: Lawrence Erlbaum Associates, Inc.

Büyüköztürk, Ş., Kılıç Çakmak, E., Akgün, Ö. E., Karadeniz, Ş., \& Demirel, F. (2014). Bilimsel araştırma yöntemleri (Scientific research methods). (17. bs). Ankara: Pegem Akademi Yaymları.

Chalk, K., \& Bizo, L. A. (2004). Specific praise improves on-task behaviour and numeracy enjoyment: A study of year of pupils engaged in the numeracy hour. Educational Psychology in Practice, 20(4), 335-351.

Cook, B. G. (2002). Inclusive attitudes, strengths, and weakness of pre-service general educators enrolled in a curriculum infusion teacher preparation program. Teacher Education and Special Education, 25(3), 262-277.

Cook, B.G., Cameron, D.L. \& Tankersley, M. (2007). Inclusive teachers' attitudinal ratings of their students with disabilities. The Journal of Special Education, 40(4), 230-238.

Cullen, J. P., Gregory, J. L., \& Noto, L. A. (2010). The Teacher Attitudes Toward Inclusion Scale (TATIS) Technical Report (ED509930).

Darling-Hammond, L. (1999). Teacher quality and student achievement: a review of state policy evidence. Center for the Study of teaching and Policy, University of Washington, http //depts.washington.edu/ctpmail/PDFs/LDH_1999.pdf

Emmer, E.T., \& Stough, L. M. (2001). Classroom management: A critical part of education. Educational Psychologist, 36(2), 103-112.

Evertson, C. M. (1989). Improving elementary classroom management: A school based training program for beginning the year. Journal of Educational Research, 83(2), 82-90.

Evertson, C.M., \& Harris, A.H. (1992). What we know about managing classrooms. Educational Leadership, 49(7), 74-78. 
Ferguson, E., \& Houghton, S. (1992). The effects of contingent teacher praise, as specified by Canter's Assertive Discipline. Educational Studies, 18(1), 83-94.

Gallagher, H.A. (2002). The relationship between measures of teacher quality and student achievement: the case of Vaughn elementary. ERIC - ED 468254

Gao, W., \& Mager, G. (2011). Enhancing preservice teachers' sense of efficacy and attitudes toward school diversity through preparation: A case of one U.S. inclusive teacher education program. International Journal of Special Education, 26(2), 92-107.

Gettinger, M., \& Kohler, K. M. (2006). Process-outcome approaches to classroom management and effective teaching. Evertson, C.M. \& Weinstein, C.S. (Ed.), Handbook of classroom management: Research, practice and contemporary issues, 3-15. Lawrence Erlbaum Associates, Inc.

Gökdere, M. (2012). Sunıf öğretmenleri ile smıf öğretmeni adaylarının kaynaştırma eğitimine yönelik tutum, endişe ve etkileşim düzeylerinin karşılaştırmalı incelemesi (A Comparative Study of the Attitude, Concern, and Interaction Levels of Elementary School Teachers and Teacher Candidates towards Inclusive Education). Educational Sciences: Theory \& Practice, 12(4), 2789-2806.

Güner-Yıldı, N. (2015a). Individuals with mental retardation from the perspective of Turkish people. Educational Research and Reviews, 10(8), 1219-1226.

Güner-Yıldız, N. (2015b). Öğretmen adaylarının kaynaştırmayla ilgili olaylara bakışı. Ahi Evran Üniversitesi Kırşehir Eğitim Fakültesi Dergisi, 16(1), 19-33.

Güner-Yıldız, N., \& Sazak-Pınar, E. (2012). Examining teachers' behavior related to students with special needs in inclusive classrooms. International Online Journal of Educational Sciences, 4(2), 475-488. 
Güner-Yıldız, N., \& Sazak-Pınar, E. (2014). Examining approval and disapproval behaviors of teachers working in inclusive classrooms. International Journal of Instruction, 7(1), $33-48$.

Güner-Yıldız, N., Sazak-Pınar, E., \& Melekoğlu, M.A. (2014). Türkiye'de sınıf yönetimi kitaplarında yetersizliği olan öğrencilere bakış (Examining Classroom Management Textbooks Published in Turkey in terms of Addressing Individuals with Disabilities). Ilkögretim Online, 13(1).

Güven, D. \& Gürsel, O. (2014). İlköğretimde kaynaştrrlan zihinsel yetersizliği olan öğrencilerin başarılarının değerlendirilmesine ilişkin öğretmen görüşleri (Educators' Opinion about the Success Evaluation of Students with Intellectual Disabilities Included In Primary Education). Ilkögretim Online, 13(1), 109-129.

Hanline, F.H. (2010). Preservice teachers' perceptions of field experiences in inclusive preschool settings: implications for personnel preparation. Teacher Education and Special Education, 33(4), 335-351.

Hansen, J.H. (2012). Limits to inclusion. International Journal of Inclusive Education, 16(1), 89-98.

Hemmings, B. \& Woodcock, S. (2011). Preservice teachers' views of inclusive education: a content analysis. Australasian Journal of Special Education, 35(2), 103-116.

Jones, V. \& Jones, L. (2001). Comprehensive classroom management creating communities of support and solving problems. 7.Edition. Pearson Education, Inc.

Jordan, A., Schwartz, E., \& McGhie-Richmond, D. (2009). Preparing teachers for inclusive classrooms. Teaching and Teacher Education, 25(4), 535-542.

Kargın, T., Güldenoğlu, B. \& Şahin., F. (2010). Genel eğitim smıflarındaki özel gereksinimli öğrenciler için yapılması gereken uyarlamalara ilişkin smif öğretmenlerinin görüşlerinin incelenmesi (Opinions of the General Education Teachers on the Adaptations for 
Students with Special Needs in General Education Classrooms). Educational Sciences: Theory \& Practice, 10(4), 2431-2464.

Killoran, I., Woronko, D. \& Zaretsky, H. (2013). Exploring preservice teachers' attitudes towards inclusion. International Journal of Inclusive Education, 18(4):427-442.

Korkmaz, İ. (2011). Elementary teachers' perceptions about implementation of inclusive education. US-China Education Review, 8(2), 177-183.

Kosir, K. \& Tement, S. (2013). Teacher-student relationship and academic achievement: a cross-lagged longitudinal study on three different age groups. Eur J Psychol Educ, 29, 409-428.

Kunter, M., Baumert, J., \& Köller, O. (2007). Effective classroom management and the development of subject-related interest. Learning and Instruction, 17(5), 494-509.

Landrum, T. J., \& Kauffman, J. M. (2006). Behavioral approaches to classroom management. In C. M. Evertson, \& C. S. Weinstein (Eds.), Handbook of classroom management: Research, practice and contemporary issues, (pp 3-15). Lawrence Erlbaum Associates, Inc.

La Salle, T.P., Roach, A.T., \& McGrath, D.C. (2013). The relationship of IEP quality to curricular access and academic achievement for students with disabilities. International Journal of Special Education, 28(1).

Available at: http://www.internationaljournalofspecialeducation.com/articles.cfm

Lemberger, M. E., \& Clemens, E. V. (2012). Connectedness and self-regulation as constructs of the Student Success Skills program in inner-city African-American elementary students. Journal of Counseling and Development, 90(4), 450-458. doi:10.1002/j.15566676.2012.00056.x

Logan, K. R., Bakeman, R., \& Keefe, E. B. (1997). Effects of instructional variables on engaged behavior of students with disabilities in general education classrooms. Exceptional Children, 63, 481- 497. 
McGee, M.R. (2001).Measuring effective teaching in inclusive classrooms. Thesis (M.A.)University of Toronto.

McIntosh, R., Vaughn, S., Schumm, J. S., Haager, D., \& Lee, O. (1993). Observations of students with learning disabilities in general education classrooms. Exceptional Children, 60(3), 249-261.

Marzano, R. J., Marzano, J. S., \& Pickering, D. J. (2003). Classroom management that works: research-based strategies for every teacher. Virginia: ASCD

Morrison, W.F., \& Rude, H.A. (2002). Beyond textbooks: a rationale for a more inclusive use of literature in preservice special education teacher programs. Teacher Education and Special Education, 25(2), 114-123.

Özer, Y. \& Anıl, D. (2011). Öğrencilerin fen ve matematik başarılarını etkileyen faktörlerin yapısal eşitsel modeli ile incelenmesi (Examining the factors affecting students' science and mathematics achievement with structural equation modelling). Hacettepe Üniversitesi Eğitim Fakültesi Dergisi, 41, 313-324.

Phillipson, S. \& Phillipson, S.N. (2012). Childrens' cognitive ability and their academic achievement: the mediation effects of parental expectations. Asia Pacific Education Review, 13(3), 495-508.

Recchia, S. L., \& Puig, V. I. (2011). Challenges and inspirations: student teachers' experiences in early childhood special education classrooms. Teacher Education \& Special Education, 34(2), 133-151. doi:10.1177/0888406410387444

Ruble, L., \& McGrew, J. H. (2013). Teacher and child predictors of achieving iep goals of children with Autism. Journal of Autism and Developmental Disorders, 43(12), 27482763. doi: 10.1007/s10803-013-1884-x

Sadioğlu, Ö., Bilgin, A., Batu, S. \& Oksal, A. (2013). Sinıf öğretmenlerinin kaynaştırmaya ilişkin sorunları, beklentileri ve önerileri (Problems, Expectations, and Suggestions of 
Elementary Teachers Regarding Inclusion). Educational Sciences: Theory \& Practice, 13(3), 1743-65

Sakı, H. \& Woods, C. (2015). Achieving inclusion of students with disabilities in Turkey: current challenges and future prospects. International Journal of Inclusive Education, 19(1), 21-35.

Savaş, B. \& Gürel, R. (2014). The variables affecting the success of students. Educational Research and Reviews, 9(1), 41-50.

Sazak-Pmar, E., \& Güner-Yıldı, N. (2013). Investigating teachers' approval and disapproval behaviors towards academic and social behaviors of students with and without special needs. Educational Sciences: Theory \& Practice, 13(1), 541-556.

Segedin, L. (2012). Listening to the student voice: understanding the school-related factors that limit student success. Journal of Education, 47(1).

Simonsen, B., Fairbanks, S., Briesch, A., Myers, D. \& Sugai, G. (2008). Evidence-based practices in classroom management: considerations for research to practice. Education and Treatment of Children, 31(3), 351-380.

Smith, R. M. (2000). Mystery or typical teen? The social construction of academic engagement and disability. Disability and Society, 15(6), 909-922.

Soodak, L.C., \& McCarthy, M. R. (2006). Classroom management in mclusive settings. Evertson, C. M., \& Weinstein, C. S. (Ed.), Handbook of classroom management: Research, practice and contemporary issues, 3-15. Lawrence Erlbaum Associates, Inc.

Sucuoğlu, B., Bakkaloğlu, H., İşcen-Karasu, F., Demir, Ş. \& Akalın, S. (2014). Okul öncesi öğretmenlerinin kaynaştırmaya ilişkin bilgi düzeyleri (Preschool Teachers' Knowledge Levels about Inclusion). Educational Sciences: Theory \& Practice, 14(4), 1467-1485.

Swinson, J., \& Harrop, A. (2001). The differential effects of teacher approval and disapproval in junior and infant classrooms. Educational Psychology in Practice, 17(2), 157-167. 
Thaver, T. \& Lim, L. (2014). Attitudes of pre-service mainstream teachers in Singapore towards people with disabilities and inclusive education. International Journal of Inclusive Education, 18(10), 1038-1052.

Thomson, C. (2013). Collaborative consultation to promote inclusion voices from the classroom. International Journal of Inclusive Education, 17(8), 882-894.

Tomlinson, C., \& Jarvis, J. M. (2014). Case studies of success: Supporting academic success for students with high potential from ethnic minority and economically disadvantaged backgrounds. Journal for the Education of the Gifted, 37, 191-219.

Van Laarhoven, T., Munk, D.D., Lynch, K., Wyland, S., Dorsch, N., Zurita, L., Basma, J. \& Rouse, J. (2006). Project ACCEPT: Preparing pre-servive special and general educators for inclusive education. Teacher Education and Special Education, 29(4), 209-212.

Varher, G. \& Vuran, S. (2006). Okul öncesi eğitimi öğretmenlerinin kaynaştırmaya ilişkin görüşleri (The Views of Pre-School Teachers about Integration). Educational Sciences: Theory \& Practice, 6(2), 553-585.

Walton, E. \& Rusznyak, L. (2014). Affordances and limitations of a special school practicum as a means to prepare pre-service teachers for inclusive education. International Journal of Inclusive Education, 18(9), 957-974.

Wang, M.C., Haertel, G.D., \& Walberg, H.J. (1994). What helps students learn?. Educational Leadership, 51(4), 74-79.

Wright, S. P., Horn, S. P., \& Sanders, W. L. (1997). Teacher and classroom context effects on student achievement: Implications for teacher evaluation. Journal of Personnel Evaluation in Education, 11, 57-67. 